\title{
Zircon - A Robust Insight to the Process of Crustal Evolution
}

\author{
C.B.Verma ${ }^{1}$, Abhijeet Mukherjee ${ }^{2}$, Neeraj Vishwakarma ${ }^{3}$, G. Prabhakar ${ }^{4}$ \\ ${ }^{1,2}$ NMDC Limited, Khanij Bhavan, Masab Tank Hyderabad-500028, \\ ${ }^{3}$ Department of Applied Geology, National Institute of Technology, Raipur, Chhattisgarh, \\ ${ }^{4}$ Department of Geology, University collage of Science, Saifabad, Osmania University, Hyderabad-500004
}

\begin{abstract}
Where would be our knowledge about early history of earth without zircon? Zircon, tiny but timely are able to provide a picture of evolution of crust and mantle. Zircon due to its robust characteristic has been long recognized as a suitable candidate playing a key role in crustal evolution studies as a best geochronometers. Recent development in analytical techniques such as high precision mass spectrometry and verity of microscopic imaging methods permits investigation of complex grain at high spatial resolution. Coupled measurement of the isotopes of oxygen and hafnium provide insight into the crust differentiation and the processes involved in crustal evolution. Such information from zircon is an invaluable help to geochemist and other earthscientist to unravel even more complex geological system.
\end{abstract}

\section{Introduction}

Zircon, $\mathrm{ZrSiO}_{4}$, is a mineral of singular importance in earth science. Zircon is the most versatile chronometer available to modern geologist. What makes zircon unique among geochronometers is its robustness: it is hard, refractory mineral that can remain intact even if its host rock is metamorphosed melted or mechanically weathered away. Furthermore, rates within zircon for many elements are extremely low, so this mineral commonly retains age and other isotopic information even when exposed to magmatic temperature.

Zircon is being used in addressing the range of earth problems such as $\mathrm{Lu} / \mathrm{Hf}$ ratio evidence that is critical for models of formation and growth of continental crust (Scherer, et. al., 2007). As a phase that can accommodate significant amounts of temperature- or process-sensitive trace elements, including the rare earth elements (REE, or lanthanides), yttrium (Y) and titanium (Ti), zircon can also provide compelling chemical evidence for the mineral-melt-fluid processes operating during crust formation and maturation, hydrothermal alteration and diagenesis (Hanchar and van Westrenen 2007; Harley et al. 2007; Geisler et al. 2007).Despite the ravages of cycling through and in the crust, zircon potentially contains a record, in its oxygen isotope composition, of the role of low temperature versus high-temperature processes in defining the character of source regions for melts (Valley 2003). Measurements of the U, Th and He contents of zircon can be used to infer the rates at which recently active landscapes developed and the times at which the exposed rocks cooled to near surface temperatures.

Central to all of these applications is the behavior of zircon in complex Earth systems. Thanks to important developments in secondary ion mass spectrometry (SIMS), laser- ablation induced coupled plasma mass spectrometry (LA-ICP-MS) and low-blank thermal-ionization mass spectrometry (TIMS), we are now able to accurately and precisely measure a battery of useful trace element and isotopic signatures in zircon. The interpretation of these isotopic and compositional data in terms of ages, isotopic reservoirs and processes requires the careful and systematic integration of microanalysis with petrology and mineral characterization. In this study we explore the remarkable mineral zircon, its characteristic and its applicability as a monitor of complex geological systems.

\section{Zircon - a robust phase $\&$ its utility}

Zircon a common accessory mineral found in various rock types is a tetragonal orthosilicate mineral in which isolated $\mathrm{SiO}_{2}$ tetrahedra are linked through shearing their edges and corner with intervening $\mathrm{ZrO}_{8}$ dodecahedera (Fig.1). These $\mathrm{ZrO}_{8}$ dodecahedra share edges to form zigzag chains along the $b$ axis, whereas along the $c$ axis, edges are shared with the $\mathrm{SiO}_{4}$ tetrahedra to produce chains with alternating $\mathrm{SiO}_{4}$ and $\mathrm{ZrO}_{8}$ polyhedra.

The overall structure of zircon is relatively open, with unoccupied space represented by the channels parallel to the $c$ axis and the void volumes bounded by $\mathrm{SiO}_{4}$ and $\mathrm{ZrO}_{8}$ polyhedra, as shown in Fig.1. This structure results in zircon's moderately high density, $4.66 \mathrm{~g} \mathrm{~cm}^{-3}$, and also contributes significantly to its very low absolute thermal expansion and compressibility and to the anisotropy of these parameters. Although pure zircon is highly incompressible, it is anisotropic in its compressibility because the $\mathrm{Zr}-\mathrm{O}$ bonds parallel to the $c$ axis are able to shorten preferentially. These properties make pure zircon or zircon with low contents of trace elements extremely resistant to physical modification related to changes in pressure or temperature, and renders 
it an excellent refractory mineral that is potentially useful for storage of radioactive and toxic isotopes provided they have suitable ionic radii.

Zircon, even with its structural capability, would be of little use and interest to earth scientist without the substitution mechanism responsible for the incorporation of many element such as $\mathrm{P}, \mathrm{Sc}, \mathrm{Nb}, \mathrm{Hf}, \mathrm{Ti}, \mathrm{U}, \mathrm{Th}$ and REE, in trace (up to thousands of ppm) or minor (up to $3 \mathrm{wt} \%$ ) amounts. Single site and couple- cation substitution mechanism plays a major role in incorporation of elements and is based on ionic radii of the substituting cations compared with $\mathrm{Zr}^{4+}$ (ionic radius of $0.084 \mathrm{~nm}$ in 8 fold co-ordination) and $\mathrm{Si}^{4+}$ (ionic radius of $0.026 \mathrm{~nm}$ in 4 fold co-ordination) cations. There is considerable substitution of $\mathrm{Hf}^{4+}$ (ionic radius $=0.083$ ) on 8 fold $\mathrm{Zr}^{4+}$ site. $\mathrm{U}^{4+}$ (8-fold ionic radius $\left.0.10 \mathrm{~nm}\right), \mathrm{Th}^{4+}(0.105 \mathrm{~nm})$ and $\mathrm{Ti}^{4+}(0.074 \mathrm{~nm})$ can also be accommodated, generally at much lower abundance levels, on this site. Although $\mathrm{U}$ can reach wt\% levels, its concentration is usually less than $5000 \mathrm{ppm}$, while the abundances of Th $(<1000 \mathrm{ppm})$ and $\mathrm{Ti}(<120 \mathrm{ppm})$ are lower still.

The most important coupled substitution involving in both the $\mathrm{Zr}^{4+}$ and $\mathrm{Si}^{4+}$ site in zircon is "xenotime" substitution involving $\mathrm{Y}$ and REE substitution for $\mathrm{Zr}$ and charge balancing $\mathrm{P}^{+5}$ (4 fold ionic radius $0.029 \mathrm{~nm}$ ) substituting for Si producing xenotime (Y,REE) $\mathrm{PO}_{4}$. An indication of verity of application of zircon based on chemical and physical properties is given in Table 1. The cation substitutions in zircon often lead to the production of spectacular internal textures such as oscillatory and sector zoning and are interpreted in terms of growth histories and diffusion - reaction or dissolution-reprecipitation.

\section{Zircon - a chronometer}

The potential of zircon as a mineral geo chronometer was recognized by Holmes in 1911 and due to its geochemical and physical properties zircon is widely used in geochronology. It is known that there are three distinct radioactive decay series involving parent isotopes ${ }^{238} \mathrm{U},{ }^{235} \mathrm{U}$ and ${ }^{232} \mathrm{Th}$ which produce as their final daughter products the isotopes ${ }^{206} \mathrm{~Pb},{ }^{20} \mathrm{~Pb}$ and ${ }^{208} \mathrm{~Pb}$ respectively. The whole decay process can be mathematically described by single decay equation relating the number of ultimate parent atoms remaining (e.g. ${ }^{238} \mathrm{U}$ ) and number of final radiogenic daughter atoms (e.g. ${ }^{206} \mathrm{~Pb}^{*}$ ) to time:

${ }^{206} \mathrm{~Pb} * /{ }^{238} \mathrm{U}=\mathrm{e}^{\square 238}-1$

where $\mathbf{e}$ is the exponential function, $\mathbf{t}$ is time, and $\square$ is the decay constant specific to this decay scheme, i.e. $\square \mathbf{2 3 8}=1.55125 \mathrm{e}^{-10} .{ }^{206} \mathrm{~Pb}^{*}$ refers to the radiogenic ${ }^{206} \mathrm{~Pb}$ accumulated in the crystal as a result of the decay of ${ }^{238} \mathrm{U}$. In the case of ${ }^{238} \mathrm{U}$, it takes approximately 4468 million years for half the ${ }^{238} \mathrm{U}$ initially present in the grain to decay to ${ }^{206} \mathrm{~Pb}$ - this is the half-life.

Generally, U-Pb system alone is considered in zircon geochronology as there is no natural non nuclear means of fractionating ${ }^{235} \mathrm{U}$ from ${ }^{238} \mathrm{U}$. The graphical method used for representing and assessing the systematic $\mathrm{U}-\mathrm{Pb}$ isotopic data in zircon is Concordia Diagram (Wetherill,1956) (Fig. 2 A), where mutually compatible sets of daughter/parent ratios i.e. ${ }^{207} \mathrm{~Pb} * /{ }^{235} \mathrm{U}$ that would evolve in zircon grain as time elapses since their formation (i.e. their age). The concordia curve itself is the locus of the mutually compatible or concordant ${ }^{207} \mathrm{~Pb}^{* /}{ }^{235} \mathrm{U}$ and ${ }^{206} \mathrm{~Pb}^{* /}{ }^{238} \mathrm{U}$ ratios, both of which increase outwards from the origin as the time since zircon crystallization passes by.

If we analyzed zircon grains from an undisturbed rock that is now 3000 Ma old, we would, ideally expect the ${ }^{207} \mathrm{~Pb}^{*} /{ }^{235} \mathrm{U}$ and ${ }^{206} \mathrm{~Pb} * /{ }^{238} \mathrm{U}$ ratios to be preserved and lie of the Concordia curve at the point corresponding to $3000 \mathrm{Ma}$. on Fig. 2A such type of zircon are concordant zircon grains: in which, two $\mathrm{Pb} * / \mathrm{U}$ ratios as measured in the grains correspond to the same age (time elapsed), and the position along Concordia is a direct measure of age and where zircon grain whose $\mathrm{Pb} * / \mathrm{U}$ analyses do not lie on Concordia are said to be discordant. They are normally discordant if they lie below the Concordia curve, which is the usual type of discordancy, and are termed reverse discordant if the analyses lie above the Concordia curve (i.e. at a higher ${ }^{206} \mathrm{~Pb}^{*} /{ }^{238} \mathrm{U}$ for a given ${ }^{207} \mathrm{~Pb} * /{ }^{235} \mathrm{U}$ ratio). The various case or situation for discordant zircon and its interpretation is illustrated in Fig. 2A, 2B \& 2C.

\section{Zircon - a tracer of crust evolution}

Hafnium ( $H f$ ) isotope analysis of U-Pb-dated zircon can reveal the relative contributions of juvenile (directly mantle-derived) crust versus recycled continental crust, making zircon a 'one-stop shop' for assessing crustal evolution.

The earth is assumed to have the same composition as that of chondritic uniform reservoir (CHUR) which is defined by undifferentiated meteorites and refractory element such as Lu \& Hf remained in silicate portion of earth (i.e. bulk silicate earth or BSE) during early core segregation, hence the BSE is expected to have the same Lu/Hf values as CHUR. The beta decay of ${ }^{176} \mathrm{Lu}$ to ${ }^{177} \mathrm{Hf}$ has a half life of 37 billion years (Scherer et. al., 2007). Hf isotopes are concentrated and bound in Zircon crystal lattice and have very low Lu/Hf ratio 
$(<0.001)$. Zircon preserve close to the initial ${ }^{176} \mathrm{Hf} /{ }^{177} \mathrm{Hf}$ inherited from the magma at the time of formation, as zircon are highly robust and have high $\mathrm{Hf}$ content $(\sim 1 \%)$ invulnerable to the process/ alteration disturbing isotopic system, with low diffusion rate of $\mathrm{Hf}$ within crystal and so gradient in ${ }^{176} \mathrm{Hf} /{ }^{177} \mathrm{Hf}$ within zircon grain reflect the variation in magma, contributing toward unraveling the compositional evolution of magma.(Fig. $3 \mathrm{~A}$ \& 3B)

Hf isotopes provide information on the source of the magmatic rock from which each zircon crystallized they tell whether the magmatism involved young mantle-derived input ("juvenile" source), if only pre-existing crust was involved (i.e. crustal reworking), or a combination of these processes. The basis of using the $\mathrm{Hf}$ isotopic ratios is the decay of ${ }^{176} \mathrm{Lu}$ to ${ }^{176} \mathrm{Hf} /{ }^{177} \mathrm{Hf}$ is a stable isotope. During mantle melting, $\mathrm{Hf}$ is partitioned more strongly into the melts than Lu. Over time ${ }^{176} \mathrm{Hf} /{ }^{177} \mathrm{Hf}$ therefore evolves to higher values in the mantle than in crustal rocks. Thus in magmatic rocks, high values of ${ }^{176} \mathrm{Hf} /{ }^{177} \mathrm{Hf}$ (i.e. $\varepsilon \mathrm{Hf}>>0$ ) indicate "juvenile" mantle input (either directly via mantle-derived mafic melts, or by remelting of young mantle-derived lower crust). Low values of ${ }^{176} \mathrm{Hf} /{ }^{177} \mathrm{Hf}(\varepsilon \mathrm{Hf}<0)$ provide evidence for the reworking of older crustal material.

$\mathrm{Lu} / \mathrm{Hf}$ data of Archaean to Hadean zircon grains from different parts of world, it is assumed that data the transition from uniform to heterogeneous $\varepsilon \mathrm{Hf}^{(t)}$ with time marks the onset of major silicate differentiation in early earth and the data from Jack hill, Western Australia zircons suggest that such differentiation must have already started by $4.4 \mathrm{Ga}$.

Oxygen stable isotope data whose fractionation is time dependent is greatly used in reducing the ambiguity, such as source of isotopic signatures in zircon i.e. they are derived from mixed juvenile and recycled source, or from mantle derived precursor that have simply aged in deep crust, which is difficult to distinguish by using radiogenic isotope only. Studies have established that oxygen diffusion in zircon is sufficiently sluggish that the original igneous $\delta^{18} \mathrm{O}$ remains intact even through protracted metamorphism and crustal fusion (King et.al., 1998, Peck et.al., 2003). The ${ }^{18} \mathrm{O} /{ }^{16} \mathrm{O}$ ratio, expressed as $\delta^{18} \mathrm{O}$ relative to SMOW is only changed by low temperature and surficial processes and so the $\delta^{18} \mathrm{O}$ of mantle derived magmas $(5.7+/-0.3 \%)$ contrast with those rocks having experienced a sedimentary cycle or hydrothermal alteration which have elevated $\delta^{18} \mathrm{O}$. This is also reflected in high $\delta^{18} \mathrm{O}$ of crystallizing zircon and is used as fingerprint for recycled component of crust in zircon. Thus Oxygen isotope Data from zircon helps us to weed out zircon grains that might give spurious crustal residence ages.

In addition to this, Zircon chemistry particularly trace and REE is used as first order distinction between the major tectonic setting under which parent magma generated, generally zircon that crystallize from intra plate A type granites have markedly different trace element composition from those formed from subduction related or orogenic magmas.

\section{Discussion}

Models for the evolution of the early continental crust require representative data on the timing of major magmatic events, clear evidence as to which represent periods of significant crustal growth as opposed to reworking of the pre-existing crust, and knowledge of the tectonic setting of crust generation and how that may have changed with time. Zircon U-Pb geochronology and Concordia diagram can be read to reveal several pieces of geological information as shown through microanalytical and microtextural studies that zircon preserve more than one period of growth or grain modification. Analyses of such types of grains are used to constrain the age and modification related to major magmatic event during the evolution of early crust.

$\mathrm{Hf}$ isotope signature constrain on the timing of mantle differentiation, Hadean zircon grains indicate and leaves little doubt that major mantle differentiation occurred at $>4.3 \mathrm{Ga}$. The combination of high precision ages and $\mathrm{Hf}$ and $\mathrm{O}$ isotope data from zircon distinguishes magmatic events that represent periods of new crustal growth and those that primarily involved the reworking of the pre-existing crust. It further allows investigation of the evolution of the igneous portion of the continental crust separate from that involved in erosion and sedimentation.

It is noteworthy to say that, no longer just a geochronometer, zircon now doubles as a detailed archive of earth growth and recycling history of earth crust and provide us the robust insight into the process involved. Our knowledge about the early history of earth crust is greatly enhanced in light of the data and information obtained from the robust phase Zircon.

\section{References}

[1]. Amelin, Y., Lee, D.-C., Halliday, A.N., 2000. Early-middle Archaean crustal evolution deduced from Lu-Hf and U-Pb isotopic studies of single zircon grains. Geochim. Cosmochim. Acta 64, 4205-4225.

[2]. Geisler T, Schaltegger U, Tomaschek F (2007) Re-equilibration of zircon in aqueous fluids and melts. Elements 3: 43-50

[3]. Hawkesworth, C. J. \& Kemp, A. I. S. (2006). Using hafnium and oxygen isotopes in zircons to unravel the record of crustal evolution. Chemical Geology 226, 144-162.

[4]. Hanchar JM, van Westrenen W (2007) Rare earth element behaviour in zircon-melt systems. Elements 3: 37-42.

[5]. Harley SL, Kelly NM, Möller A (2007) Zircon behaviour and the thermal histories of mountain chains. Elements 3: 25-30 
[6]. King, E.W., Valley, J.W., Davis, D.W., Edwards, G.R., 1998. Oxygen isotope ratios of Archaean plutonic zircons from granitegreenstone belts of the Superior Province: indicator of magmatic source. Precambrian Res. 92, 47-67.

[7]. Peck,W.H., Valley, J.W., Graham, C.M., 2003. Slow diffusion rates of O isotopes in igneous zircons from metamorphic rocks. Am.Mineral. 88, 1003-1014.

[8]. Scherer EE, Whitehouse MJ, Münker C (2007) Zircon as a monitor of crustal growth. Elements 3: 19-24.

[9]. Valley, J.W., 2003. Oxygen isotopes in zircon. Rev. Mineral. Geochem. 53, 343- 380.

[10]. Wetherill GW (1956) Discordant uranium lead ages, I. Transactions of the American Geophysical Union 37: 320-326

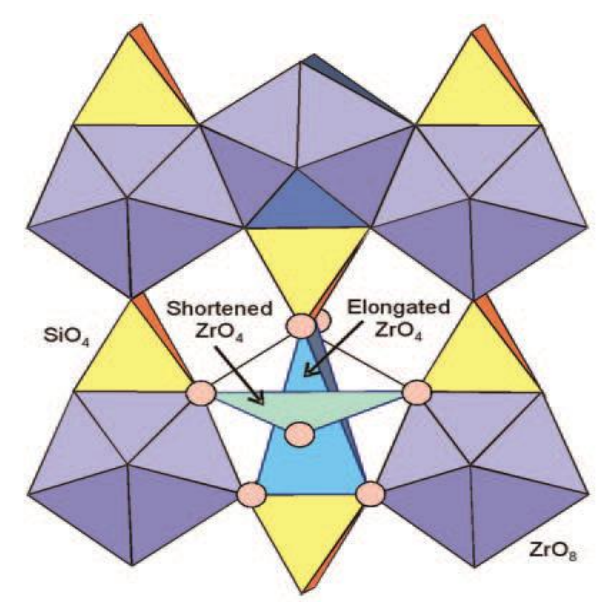

Fig.1. A view of the zircon structure $\mathrm{SiO} 4$ tetrahedra are coloured yellow, and $\mathrm{ZrO}_{8}$ dodecahedra are in shades of blue. One dodecahedron is unshaded to reveal its sub-structure consisting of two distorted $\mathrm{ZrO}_{4}$ tetrahedra. The elongated $\mathrm{ZrO}_{4}$ tetrahedra share upper and lower edges with the $\mathrm{SiO}_{4}$ tetrahedra.

\begin{tabular}{|c|c|c|c|}
\hline $\begin{array}{l}\text { Chemical / Physical } \\
\text { Property }\end{array}$ & $\begin{array}{l}\text { Substitutions / other } \\
\text { points to note }\end{array}$ & Key application & Comments \\
\hline $\begin{array}{l}\text { U and Th } \\
\text { U up to } 5000 \mathrm{ppm} \\
\text { Th up to } 1000 \mathrm{ppm}\end{array}$ & $(\mathrm{U} 4+, \mathrm{Th} 4+)=\mathrm{Si} 4+$ & $\mathrm{U}-\mathrm{Pb}$ geochronology & $\begin{array}{l}\text { A concordia diagram can be used to } \\
\text { evaluate the isotopes of } \mathrm{U} \text { and their } \mathrm{Pb} \\
\text { decay products. Th/ } \mathrm{U} \text { ratios, used in the } \\
\text { past to distinguish magmatic from } \\
\text { metamorphic and hydrothermal zircon, } \\
\text { must be treated with caution. }\end{array}$ \\
\hline $\mathrm{He}$ & $\begin{array}{l}\text { Formed by decay } \\
\text { of } U \text { and } T h\end{array}$ & $\begin{array}{l}\text { Determination of } \\
\text { exhumation and landscape } \\
\text { development rates using U- } \\
\text { Th-He thermochronometry }\end{array}$ & $\begin{array}{l}\text { Low-temperature chronometry is based } \\
\text { on the closure of zircon to He loss. This } \\
\text { method gives an age related to the time } \\
\text { the zircon cooled through } \sim 40^{\circ} \mathrm{C} \text {. }\end{array}$ \\
\hline $\begin{array}{l}\text { Hf } \\
\text { HfO2 mostly }<3 \text { wt } \%\end{array}$ & $\mathrm{Hf} 4+=\mathrm{Si} 4+$ & $\begin{array}{l}\text { Investigation of crustal } \\
\text { residency and continental } \\
\text { growth; crustal versus } \\
\text { mantle sources of magmas in } \\
\text { which zircon formed }\end{array}$ & $\begin{array}{l}{ }^{176} \mathrm{Lu} \text { decays to }{ }^{176} \mathrm{Hf} \text {. High } \mathrm{Hf} / \mathrm{Lu} \text { in } \\
\text { zircon means its ratio } \\
\text { of }{ }^{176} \mathrm{Hf} /{ }^{177} \mathrm{Hf} \text { changes very little with } \\
\text { time, so it can be used to infer sources } \\
\text { by reference to an Earth model. }\end{array}$ \\
\hline $\begin{array}{l}\text { Ti } \\
\text { Ti up to } 120 \mathrm{ppm}\end{array}$ & $\mathrm{Ti} 4+=\mathrm{Si} 4+$ & Ti in zircon thermometry & $\begin{array}{l}\mathrm{Ti} \text { is maximised when zircon is in } \\
\text { equilibrium with rutile. Ti thermometry } \\
\text { can yield } \mathrm{T} \text { of zircon crystallization, } \\
\text { which usually occurs late in the cooling } \\
\text { of a magma, or } \mathrm{T} \text { of metamorphic } \\
\text { zircon growth with rutile. }\end{array}$ \\
\hline $\begin{array}{l}\text { Y and REE } \\
\text { Y mostly }<5000 \mathrm{ppm} \\
\text { Total REE }<2500 \mathrm{ppm}\end{array}$ & $\begin{array}{l}(\mathrm{Y} 3+, \text { REE3+)P5+ = } \\
\mathrm{Zr} 4+\mathrm{Si} 4+\end{array}$ & $\begin{array}{l}\text { Reconstruction of magmatic } \\
\text { histories; } \\
\text { fingerprinting of magma } \\
\text { sources; tuning of ages to } \\
\text { mineral reactions }\end{array}$ & $\begin{array}{l}\text { Requires extensive knowledge of trace } \\
\text { element partitioning among zircon, } \\
\text { melts and competitor minerals over a } \\
\text { range of } \mathrm{P}, \mathrm{T} \text {, composition and oxygen } \\
\text { fugacity conditions. }\end{array}$ \\
\hline O isotope composition & & $\begin{array}{l}\text { Fingerprinting the } \\
\text { contribution of sediments } \\
\text { and crust to the sources of } \\
\text { magmas; examining crustal } \\
\text { recycling }\end{array}$ & $\begin{array}{l}\text { Significant fractionation of }{ }^{18} \mathrm{O} \text { from }{ }^{16} \mathrm{O} \\
\text { occurs at low } \mathrm{T} \text {. Variations in }{ }^{18} \mathrm{O} /{ }^{16} \mathrm{O} \\
\text { isotopic composition of zircon are used } \\
\text { to determine the role of sources that } \\
\text { have been affected by low- } \mathrm{T} \\
\text { fractionation. }\end{array}$ \\
\hline
\end{tabular}

Table1: Key Chemical Feature of Zircon and their application. 

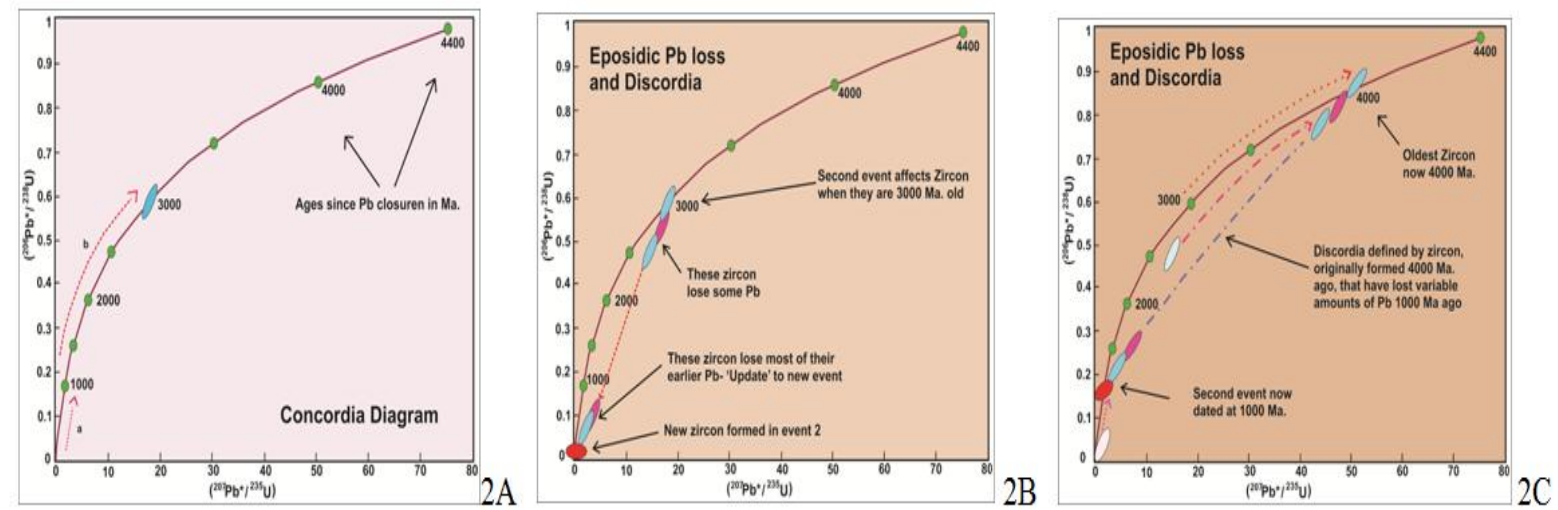

Fig. 2A - Concordia diagram, the axes are the ratios of the radiogenic daughter $\mathrm{Pb}$ isotopes divided by their respective parent $\mathrm{U}$ isotope. The Concordia curve traces out the compatible ratios as they develop with time elapsed since the moment the 'clocks' are set in newly formed zircon, and is annotated with this time elapsed, or 'age'. Lines a and b show the evolution of the compatible ratios in 1000 and 3000 Ma zircon respectively.

Fig. 2B \& 2C - Concordia diagram and episodic Pb loss, Variable loss of Pb from older zircon grains, arising because of the effects of a second event, produces a Discordia between the older formation age (now $4000 \mathrm{Ma}$ ) and the age of the second event (1000 Ma).
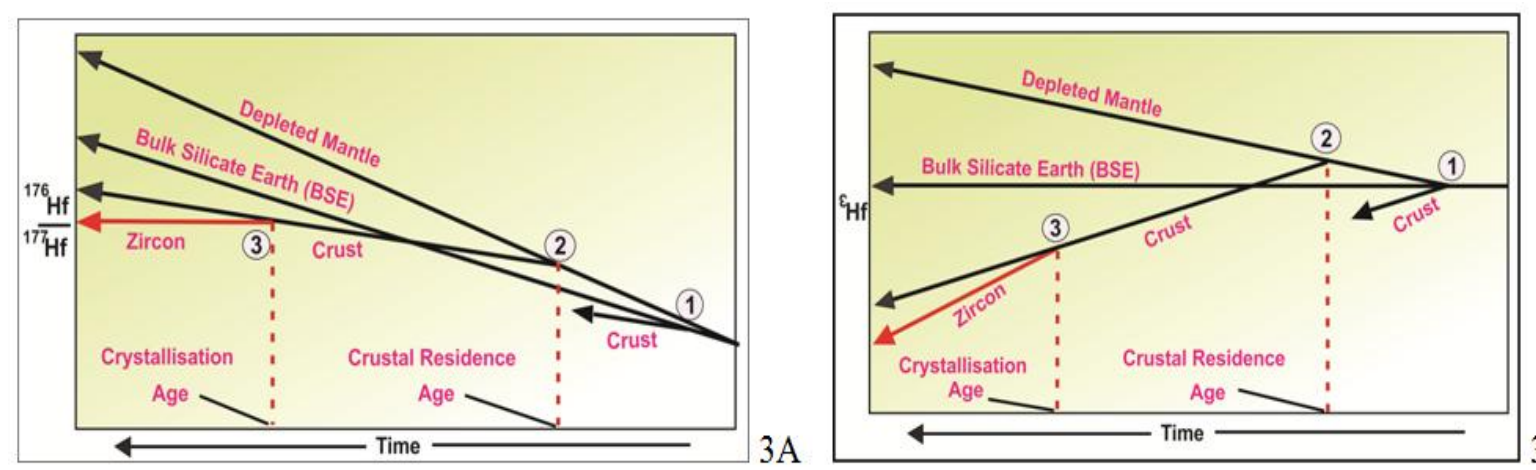

Fig. 3(A) Hypothetical evolution of 176Hf/177Hf versus time for the bulk silicate Earth (BSE), depleted mantle (DM), two crustal reservoirs, and zircon. Fig.3 (B) The same reservoirs plotted as $\varepsilon \operatorname{Hf}(t)$ versus time. The U-Pb age of a zircon dates its crystallization (3); the Lu-Hf residence age estimates the time elapsed since the crustal domain hosting the zircon was extracted from the depleted mantle (2). 